mittees, and travellers themselves. Such recommendations are more than pious hopes: the report describes various health and local authority initiatives in Essex, Medway, east London, East Anglia, Sheffield, and Liverpool as examples of good practice. They should encourage other authorities to take the plunge.

One of the unresolved issues for travellers' health care is the balance between specialist "outreach" services such as mobile health caravans $s^{5}$ and integration into existing general practice and community health services. ${ }^{12}$ Integration is hampered by discrimination on the part of some health care providers as well as the mobility of travellers, their lack of postal addresses for appointments, and their low literacy rate. Travellers also have different cultural perceptions of health and illness from most health workers. ${ }^{13}$ These barriers to health care require imaginative solutions, such as the use of hand held medical record cards and mutual education of travellers and health care providers. Sadly, the new contract for general practitioners may inadvertently discourage the registration of travellers, especially in practices struggling to meet immunisation and cytology targets.

We need research on travellers' health needs and health perceptions as well as evaluation of interventions such as hand held record cards, educational initiatives, and increased liaison between different agencies concerned with travellers' health. Already, however, we know enough for authorities to take action. The government's new health service legislation charges district health authorities with responsibilty for assessing the health needs of their populations and purchasing the appropriate services. The Maternity Alliance report is a timely reminder to health authorities not to overlook the needs of travellers.

GENE FEDER

Research Fellow,

Department of General Practice and Primary Care,

Medical Colleges of St Bartholomew's and the London Hospitals, London EC1

Senior Lecturer

RUTH HUSSEY

Department of Public Health

University of Liverpool,

Liverpool L69 3BX

1 Department of the Environment. Count of gypsy caravan sites 18 fanuary 1989. London: DoE, 1989.

2 Puxon G. Rama: Europe's gypsies. Report No 14. London: Minority Rights Group, 1987.

3 Golding AMB. The health needs of homeless families. I R Coll Gen Pract 1987;37:433-4.

4 Cornwell J. Improving health care for travellers. London: King's Fund Centre, 1984.

4 Cornwell J. Improving health care for travellers. London: King's Fund Centre, 1984.

5 Streetly A. Health care for travellers: one year's experience. $\mathrm{Br}$
6 Walker PC. The health of travellers. Br Med f 1986;293:1321.

6 Walker PC. The health of travellers. Br Med f 1986;293:1321.
7 Hussey RM. Travellers and preventive health care. Br Med f 1988;296: 1098.

7 Hussey RM. Travellers and preventive health care. Br Med f 1988;296:1098. 1990

9 Pahl J, Vaile M. Health and health care among travellers. Canterbury: University of Kent Health Services Research Unit, 1986.

10 Barry J, Herity B, Solan J. The traveller health status study: vital statistics of travelling people 1987. Dublin: Health Research Board, 1989.

11 Linthwaite P. Health and health care in traveller mothers and children. London: Save the Children Fund, 1983.

12 Feder G. Traveller gypsies and primary care. $7 R$ Coll Gen Pract 1989;39:425-9.

13 Oakley J. The traveller-pypsies. Cambridge: Cambridge Universiry Press, 1983.

\title{
Management of menorrhagia
}

\section{Hysteroscopic techniques offer a revolution in treatment}

Excessive menstrual bleeding is a common complaint of women during their reproductive years and accounts for many consultations.' Unfortunately, the history is a poor index of genuine menorrhagia as only two fifths of women who complain of flooding, the passage of clots, and heavy use of tampons or pads actually lose more than $80 \mathrm{ml}$ of blood per cycle - that is, more than the 90th centile limit for a normal population..$^{23}$ Although the history is a better indicator of menorrhagia in the presence of pelvic disease, particularly uterine fibroids, ${ }^{4}$ the only reliable way of confirming the diagnosis is by measuring the blood loss. ${ }^{5}$ Such measurement, however, remains essentially a research tool, although various modifications of the commonly used alkaline haematin method have been suggested for everyday use. ${ }^{6}$ A more realistic diagnostic aid is the assessment of blood haemoglobin or serum ferritin concentration as two thirds of women with objective menorrhagia suffer from iron deficiency anaemia. ${ }^{2}$ Recently, pictorial menstrual charts have been described that may also improve diagnostic accuracy.

Once menorrhagia has been diagnosed its cause needs to be identified. The common causes include fibroids, endometriosis, endometrial hyperplasia, and, in the absence of identifiable disease, "dysfunctional uterine bleeding." general examination looking for signs of hypothyroidism or a bleeding tendency should be combined with pelvic assessment and, because of the potential risk of endometrial malignancy or premalignancy, with outpatient endometrial sampling in women aged over $40 .{ }^{9}$ Dilatation and curettage is not only unnecessarily invasive but it also offers no guarantee of detecting intrauterine disease ${ }^{1011}$ and is not therapeutic in most cases. ${ }^{12}$ Instead, there is increasing evidence that hysteroscopy, carried out as an outpatient procedure, is the best technique for assessing the endometrial cavity, endometrial polyps and submucous fibroids being found in up to half of all patients with menorrhagia. ${ }^{131+}$ The possible role of psychological factors should also not be forgotten. ${ }^{15}$

Treatment should take account of the likely diagnosis as well as the age of the patient, her desire to maintain fertility, and the presence of other symptoms such as prolapse. There are several effective treatments, though there is no scientific evidence for the effectiveness of the most commonly prescribed agents-progestogens such as norethisterone. ${ }^{16}$ Interestingly, intrauterine contraceptive devices that release progestogen seem to be effective, and the newer formulations are not associated with a high risk of ectopic pregnancy. ${ }^{17}$ There is objective evidence for the efficacy of the combined contraceptive pill ${ }^{18}$; prostaglandin inhibitors (mefenamic acid, ${ }^{19}$ naproxen, ${ }^{20}$ indomethacin, ${ }^{21}$ ibuprofen, ${ }^{22}$ flurbiprofen, ${ }^{23}$ meclofenamate sodium ${ }^{24}$ ) even in the presence of an intrauterine contraceptive device ${ }^{2125-27}$ but not of fibroids ${ }^{2228}$; and antifibrinolytic agents ( $\varepsilon$ aminocaproic acid, ${ }^{29}$ tranexamic $\left.\operatorname{acid}^{30}\right)$, which may also be effective in cases of menorrhagia induced by intrauterine contraceptive devices ${ }^{3132}$ and the capillary stabiliser ethamsylate. ${ }^{33}$ All these agents reduce menstrual blood loss by an average of $50 \%$. Danazol ${ }^{34}$ and luteinising hormone releasing hormone agonists ${ }^{35}$ may be even more effective and produce amenorrhoea, but short term and long term side effects preclude their prolonged use. The newer agent gestrinone may prove to be better tolerated but be equally effective (M C P Rees, personal communication), even to the extent of reducing the size of fibroids. ${ }^{36}$ Tamoxifen, ${ }^{37}$ vitamin $E,{ }^{38}$ and subcutaneous desmopressin ${ }^{39}$ have also been tried in special cases with apparent success.

Medical treatments are, however, neither curative nor 
universally effective, especially in the presence of pelvic disease, and ultimately many women with menorrhagia undergo hysterectomy. Hysterectomy is the commonest major operation for women in their fertile years,,$^{+0}$ and poorly controlled menorrhagia accounts for about a third of operations. ${ }^{41}$ Although symptomatically effective and offering the possibility for prophylaxis against not only uterine but also ovarian cancer if combined with oophorectomy (and hormone replacement) ${ }^{42}$ hysterectomy for benign disorders has a mortality of $6 / 10000^{43}$ and an operative morbidity as high as $42 \cdot 8$ per 100 procedures. ${ }^{4}$ Similarly, while the psychological sequelae of surgery are generally beneficial, ${ }^{15}$ the long term adverse effects may include premature ovarian failure, ${ }^{45}$ cardiovascular disease, ${ }^{+6}$ and urinary and bowel dysfunction..$^{47+8}$

We are, however, on the threshold of a revolution in treatment. Endometrial destruction by various physical and chemical agents has been investigated for many years in an attempt to produce a therapeutic type of Asherman's syndrome with hypomenorrhoea or amenorrhoea. ${ }^{49}$ Early techniques were carried out blindly, producing incomplete destruction and inconsistent results, although the recently described treatment of radiofrequency induced thermal ablation may prove more successful. ${ }^{50}$ Improvements in optics and illumination have now led to the development of hysteroscopic techniques of endometrial ablation by laser ${ }^{51}$ or electrodiathermy $^{5253}$ and endometrial resection. ${ }^{5455}$ Direct vision makes skip lesions less likely, and this is reflected in the results. These are similar for all the endoscopic methods, with about half the patients becoming amenorrhoeic, $45 \%$ hypomenorrhoeic, and only $5 \%$ of women requesting further intervention. Treatment may also be selective, allowing resectoscopic excision of focal lesions such as polyps and submucous fibroids, particularly in those who wish to retain their fertility. ${ }^{56}$ Though these techniques are not without hazard, ${ }^{57-59}$ hysteroscopic surgery is associated with low morbidity, the potential for outpatient treatment without general anaesthesia, ${ }^{60}$ recovery within days rather than weeks, and, not least, considerable savings in cost. Hysteroscopic techniques of endometrial destruction will probably replace most hysterectomies for menorrhagia, but first their long term safety and efficacy must be fully assessed.

Senior Lecturer,

Minimally Invasive Therapy Unit,

Academic Department of Obstetrics and Gynaecology,

The Royal Free Hospital, London NW3 2QG

1 Office of Population Censuses and Surveys. Morbidity statistics from general practice 1981/1982. London: OPCS, 1986:table 13.

2 Hallberg L, Hogdahl A-M, Nilsson L, Rybo G. Menstrual blood loss-a population study. Acta Obstet Gynecol Scand 1966;45:320-51.

3 Fraser IS, McCarron G, Markham R. A preliminary study of factors influencing perception of menstrual blood loss volume. Am 7 Obstet Gynecol 1984;149:788-93.

4 Fraser IS, McCarron G, Markham R, Resta T, Watts A. Measured menstrual blood loss in women with menorrhagia associated with pelvic disease or coagulation disorder. Obstet Gynecol 1986;68:630-3.

5 Hallberg L, Nilsson L. Determination of menstrual blood loss. Scand f Clin Lab Invest 1964;16:244-8.

6 Van Eijkeren MA, Scholten PC, Christiaens GC, Alsbach GP, Haspells AA. The alkaline hematin method for measuring menstrual blood loss-a modification and its clinical use in menorrhagia. method for measuring menstrual blood loss-a modit

7 Higham JM, Shaw RW. Measured menstrual blood losses-normal population and "menorrhagia" patients. Carnforth: Parthenon, 1990:69-82.

8 Rees MCP. Clinical algorithms: menorrhagia. Br Med 7 1987;294:759-62.

9 MacKenzie IZ. Routine outpatient diagnostic uterine curettage using a flexible plastic aspiratio curette. Br f Obstet Gynaecol 1985;92:1291-6.

10 Word B, Gravlee LC, Wideman GL. The fallacy of simple uterine curettage. Obstet Gyneco 1958;12:642-8

11 Grimes DA. Diagnostic dilatation and curettage: a reappraisal. Am 7 Obstet Gynecol 1982;142:1-6.

12 Haynes PJ, Hodgson H, Anderson AM, Turnbull AC. Measurement of menstrual blood loss in patients complaining of menorrhagia. Br $\mathcal{F}$ Obstet Gynaecol 1977;84:763-8.
13 Gimpelson RJ, Rappold HO. A comparative study between panoramic hysterectomy with directed biopsies and dilatation and curettage. Am f Obstet Gynecol 1988;158:489-92.

14 Taylor PJ, Hamou JE. Hysteroscopy. F Reprod Med 1983;28:359-89.

15 Iles S, Gath D. Psychological problems and uterine bleeding. Ballière's Clin Obstet Gynaecol 1989;3:375-89.
.

16 Cameron IT, Leask R, Kelly RW, Baird DT. The effects of danazol, mefenamic acid, norethisterone and a progesterone-impregnated coil on endometrial prostaglandin concentrations in women with menorrhagia. Prostaglandin 1987;34:99-100.

17 Bergqvist A, Rybo A. Treatment of menorrhagia with intrauterine release of progesterone. Brf Obstet Gynaecol 1983;90:255-8.

18 Nilsson L, Rybo G. Treatment of menorrhagia. Am f Obstet Gynecol 1971;110:713-20.

19 Anderson ABM, Haynes PJ, Guillebaud J, Turnbull AC. Reduction of menstrual blood loss by prostaglandin-synthetase inhibitors. Lancet 1976;i:774-6.

20 Rybo G, Nilsson S, Sikström B, Nygren KG. Naproxen in menorrhagia. Lancet 1981;i:608-9.

21 Anteby SO, Yarkoni S, Ever-Hadani P. The effect of a prostaglandin synthetase inhibitor, indomethacin, on excessive uterine bleeding. Clin Exp Obstet Gynecol 1985;12:60-3.

22 Mäkäräinen L, Ylikorkala $\mathrm{O}$. Primary and myoma-associated menorrhagia: role of prostaglandins and effects of ibuprofen. Br f Obstet Gynaecol 1986;93:974-8.

23 Andersch B, Milsom I, Rybo G. An objective evaluation of flurbiprofen and tranexamic acid in the treatment of idiopathic menorrhagia. Acta Obstet Gynecol Scand 1988;67:645-8.

24 Vargyas JM, Campeau JD, Mishell DR. Treatment of menorrhagia with meclofenamate sodium. Am F Obstet Gynecol 1987;157:944-50.

25 Gillebaud J, Anderson ABM, Turnbull AC. Reduction by mefenamic acid of increased menstrual blood loss associated with intrauterine contraception. Br f Obstet Gynaecol 1978;85:53-62.

26 Yarkoni S, Anteby SO. Treatment of IUD related menorrhagia by indomethacin. Clin Exp Obstet Gynecol 1984;11:120-2.

27 Mäkäräinen L, Ylikorkala $O$. Ibuprofen prevents IUCD-induced increases in menstrual blood loss. Br F Obstet Gynaecol 1986;93:285-8.

28 Ylikorkala O, Pekonen F. Naproxen reduces idiopathic but not fibromyoma-induced menorrhagia. Obstet Gynecol 1986;68:10-2.

29 Nilsson L, Rybo G. Treatment of menorrhagia with epsilon aminocaproic acid. A double blind investigation. Acta Obstet Gynecol Scand 1965;44:467-83.

30 Nilsson L, Rybo G. Treatment of menorrhagia with an antifibrinolytic agent, tranexamic acid (AMCA). A double blind investigation. Acta Obstet Gynecol Scand 1967;46:572-80.

31 Kasonde JM, Bonnar J. Effect of ethamsylate and aminocaproic acid on menstrual blood in women using intrauterine devices. Br Med f 1975; iv:21-2.

32 Ylikorkala O, Niinikka L. Comparison between antifibrinolytic and antiprostaglandin treatment in the reduction of increased menstrual blood loss in women with intrauterine contraceptive devices. Br $\mathcal{O}$ Obstet Gynaecol 1983;90:78-83.

33 Harrison RF, Campbell S. A double-blind trial of ethamsylate in the treatment of primary and intrauterine-device menorrhagia. Lancet 1976;ii:283-5.

34 Chimbira TH, Anderson ABM, Naish C, Cope E, Turnbull AC. Reduction of menstrual blood loss by danazol in unexplained menorrhagia: lack of effect of placebo. Br $\mathrm{f}$ Obstet Gynaecol 1980;87:1152-8.

35 Shaw RW, Fraser HM. Use of superactive luteinising hormone releasing hormone (LHRH) agonis in the treatment of menorrhagia. Br f Obstet Gynaecol 1984;91:913-6.

36 Coutinho EM, Conçalves MT. Long-term treatment of leiomyomas with gestrinone. Fertil Steri 1989;51:939-46.

37 Fraser IS. Menorrhagia due to myometrial hypertrophy: treatment with tamoxifen. Obstet Gynaecol 1987;70:505-6.

38 Dasgupta PR, Dutta S, Banerjee P, Majumdar S. Vitamin E (alpha tocopherol) in the management of menorrhagia associated with the use of intrauterine contraceptive devices (IUCD). Int $\mathcal{F}$ Fertil of menorrhagias $1983 ; 28: 55-6$.

39 Vigano GL, Mannucci PM, Lattuada A, Harris A, Remuzzi G. Subcutaneous desmopressin (DDAVP) shortens the bleeding time in uremia. Am f Hematol 1989;31:32-5.

40 Dicker RC, Scally MJ, Greenspan JR, Layde PM, Ory HW, Maze JM, Smith JC. Hysterectom among women of reproductive age. Trends in the United States 1970-78. FAMA 1982;248:323-7. 41 Department of Health and Social Security, Office of Population Censuses and Surveys. Hospital in-patient enquiry, 1985. London: HMSO, 1985 :table P1.

42 Studd JWW. Prophylactic oophorectomy. Br f Obstet Gynaecol 1989;96:506-9.

43 Wingo PA, Huezo CM, Rubin GL, Ory HW, Peterson HB. The mortality risk associated with hysterectomy. Am f Obstet Gynecol 1985;152:803-8.

44 Dicker RC, Greenspan JR, Strauss LT, et al. Complications of abdominal and vaginal hysterectomy among women of reproductive age in the United States. The collaborative review of sterilisation. Am f Obstet Gynecol 1982;144:841-8.

45 Siddle N, Sarrel P, Whitehead MI. The effect of hysterectomy on the age at ovarian failure: identification of a subgroup of women with premature loss of ovarian function and literature identification of a subgroup of wom.
review. Fertil Steril 1987;47:94-100.

46 Punnonen R, Ikäläinen, Seppälä E. Premenopausal hysterectomy and risk of cardiovascular

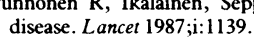

47 Parys BT, Haylen BT, Woolfenden KA, Parsons KF. Vesicourethral dysfunction after simple hysterectomy. Neurourology and Urodynamics 1989;8:315-6.

48 Taylor T, Smith AN, Fulton PM. Effect of hysterectomy on bowel function. Br Med $\mathcal{J}$ 1989;299:300-1.

49 Magos AL. Endometrial ablation techniques. In: Shaw RW, ed. Dysfunctional uterine bleeding. Proceedings of a symposium on reproductive endocrine disorders. Carnforth: Parthenon, 1990:97-115. 50 Phipps JH, Lewis BV, Roberts T, et al. Treatment of functional menorrhagia by radiofrequencyinduced thermal endometrial ablation. Lancet 1990;335:374-6.

51 Goldrath $M H$, Fuller TA, Segal S. Laser photovaporisation of endometrium for the treatment of menorrhagia. Am f Obstet Gynecol 1981;140:14-9.

52 DeCherney A, Polan ML. Hysteroscopic management of intrauterine lesions and intractable uterine bleeding. Obstet Gynecol 1983;61:392-7.

53 Vancaille TG. Electrocoagulation of the endometrium with the ball-end resectoscope. Obstet Gynecol 1989;74:425-7.

54 DeCherney AH, Diamond MP, Lavy G, Polan ML. Endometrial ablation for intractable uterine bleeding: hysteroscopic resection. Obstet Gynecol 1987;70:668-70.

55 Magos AL, Baumann R, Turnbull AC. Transcervical resection of the endometrium in women with menorrhagia. Br Med f 1989;298:1209-12.

56 Neuwirth RS. A new technique and additional experience with hysteroscopic resection of submucous fibroids. Am $\mathcal{F}$ Obstet Gynecol 1978;131:91-4

57 Morrison LMM, Davis J, Sumner D. Absorption of irrigating fluid during laser photocoagulation of the endometrium in the treatment of menorrhagia. Br $\mathcal{F}$ Obstet Gynaecol 1989;96:346-52

58 Baumann R, Magos AL, Kay JDS, Turnbull AC. Absorption of glycine irrigation solution during transcervical resection of the endometrium. Br Med $\mathcal{F} 1990 ; 300: 304-5$

59 Magos AL, Baumann R, Turnbull AC. Safety of transcervical endometrial resection. Lance 1990;335:44.

60 Magos AL, Baumann R, Turnbull AC. Intrauterine surgery under intravenous sedation as an outpatient alternative to hysterectomy. Lancet 1989;ii:925-6. 